\title{
A Case Study on Reducing Children's Screen Time: The Project of Screen Free Week
}

\author{
Hatice Gözde Ertürk Kara ${ }^{1, *}$ \\ ${ }^{1}$ Faculty of Education, Aksaray University, Aksaray, Turkey \\ *Correspondence: Faculty of Education, Aksaray University, Aksaray, Turkey. E-mail: gozdeerturk@aksaray.edu.tr
}

Received: January 31, 2018

Accepted: February 10, 2018 Online Published: February 25, 2018

doi:10.5430/wje.v8n1p100

URL: https://doi.org/10.5430/wje.v8n1p100

\begin{abstract}
The current study aims to direct children to alternative activities within a week period by applying the project of screen free week to voluntary families. The ultimate aim of the study is to reduce children's screen time. The instrumental case study method; one of the qualitative research methods, was employed. Five children attending the preschool class of an elementary school in the Kartal district of İstanbul and their families voluntarily participating in the project of screen free week constituted the study group in the current research. Documents and structured interview form were used to collect data. The document used to collect data is the weekly chart in which the families noted the activities they performed during the week spent without screen. The structured interview form was developed by the researcher by reviewing the related literature. Content analysis was conducted on the data collected in the current research. As a result of the families' participation in the project of screen free week, they recognized the importance of family-child interaction, that their children are happier when they spend time with them, that they can decide on programs to be watched and games to be played together with their children and that this decision should not be taken as a rule rather as a routine of the family. At the end of the project of screen free week, it was seen that a great majority of the families set a limit to the time spent in front of the screen suitable for the age and developmental level of their children. In light of the findings of the current study, it can be suggested that the project of screen free week should be made more widespread and more families and children should be reached. In addition to this, training programs can be organized for families to learn how to select quality programs/applications.
\end{abstract}

Keywords: Early childhood period, media, screen time, screen free

\section{Introduction}

In the literature, there are various studies looking for ways of limiting the use of media tools by children and raising the awareness of their families in this regard. The Guide to Conscious Media Use, published by Aydeniz (2012), includes suggestions about media-child relations, the effect of media on children and the correct use of media tools. The author recommends that families should take the age of their child into account while deciding the time he/she will spend on media (without screen before the age of 2, 1 hour the most for 3-7 year olds), they should reconsider the time they themselves spend in front of the screen and shorten this time to spend more time with their children, screen free environments should be created at home, the screen should be used together with the child and the child should be encouraged to be in the nature. In her thesis, Akçay (2015) examined media interactions and aggressive behaviors of children through motivational interviews conducted with a group of mothers having pre-school children. At the end of the study, it was determined that through motivational interviews, the mothers' control over the media increased (checking in advance, programmed and co-watching, clarified help, monitoring according to the smart marking classification system). Moreover, the children's aggressive behaviors were observed to be decreasing. In the study conducted by Banko, İlhan and Şallı (2017), the use of smart symbols on television by families and their methods of protecting children from harmful effects of television were examined. At the end of the study, the mothers' use of smart symbols was found to be high. Furthermore, the mothers who participated in the study also stated that they used methods such as setting a time limit, controlled TV watching and conducting other activities to protect their children from the adverse effects of TV. In a study conducted by Dorey, Roberts, Maddison, Meagher-Lundberg, Dixon \& Mhurchu (2010), it was determined that families think that limiting children's television viewing is an effective way. The participating families expressed that they were trying to get their children 
away from the TV by offering alternative activities. It is thought that providing alternative activities for children will increase the child-family interaction and will help to control the time children spend in front of the screen. Therefore, the current study aims to direct children to alternative activities within a week period by applying the project of screen free week to voluntary families. The ultimate aim of the study is to reduce children's screen time.

\subsection{Information about the Project of Screen Free Week}

\subsubsection{What is Screen Free Week?}

Screen free week means determining the time spent by children in front of the screen at home for a week and then organizing alternative activities for children to spend this time on their own, with their friends and families, instead of sitting in front of the screen. In this way, children can recognize that they can spend good time without television, computer, tablet and telephone. Even if a child does not spend much time in front of the screen, it is recommended that he/she should participate in the project of screen free week because in this way he/she can get engaged in an experience in which he/she can share with his/her friends and have a good time with his/her family. The family may notice that the child is getting more and more addicted to the screen, indicating that it is high time for him/her to participate in the project of screen free week. If this week is spent as required, then an opportunity may be created to decrease the child's desire to be in front of the screen.

During screen free week, family members can use the computer for their personal works, can check their e-mails and surf through blogs and social media for different activities to be done with the child. What is important here is to prevent the child from spending his/her time in front of the screen and thinking that the only means of fun is the screen. If the child sees his/her family members playing on their mobile phones, the main goal of the project will be distorted. Thus, being a good model for the child is important for the efficiency of the week.

\subsubsection{Why was the Screen Free Time Planned as One Week?}

It can be thought that the time spent without screen can be planned as one day, two days or one month. The reasons for limiting this time to one week can be explained as follows: This time is not shorter than one week because the child can control himself/herself without being in front of the screen for one or two days. This can be likened to having a diet. One or two-day time is seen to be not enough to understand and internalize what it really means being without screen. The reason for not keeping this time longer than a week is that some time is needed for the family and the child to change their behaviors and that the screen free life should be established by not external pressures but with the family and the child's own will. At the end of the one-week period, the family and the child decide how much time will be spent in front of the screen.

\subsubsection{Suggestions for Alternative Activities that can be Conducted during Screen Free Week}

Activities suggested in line with the purpose of the project of screen free week aim to increase family-child interaction, to get the child to spend time in out-of-school environments such as nature, museum, library and gallery and to get the child engaged in more books, music and dance. Before moving on to the suggestions for screen free week, the families said that they had to spend at least 15 minutes outdoor each day during the week. Play lie at the heart of screen free week. A variety of games were suggested for the child to play on himself/herself, with the family or friends. These game recommendations aimed to lead the family and the child to creating their own games. Besides games with rules (card and table games), some game recommendations with open-ended materials were also offered (stone, Lego, seashell etc.). At the end of the 82 recommended activities, the Children's Books List was added and families were suggested to obtain the Tubitak Merakli Minik Magazine. In addition, the following reminder was added to the beginning of the game recommendations: "Please remember that your child has the leading role in the activities! Just make sure that all the process is directed by the child and that you will only help him/her when needed and will assume the guidance role. Let him/her use his/her hands a lot. Trust him/her". Some of the alternative activity suggestions that can be made during the week are: Listen to the radio, look at magazines on nature, travel, photograph etc., teach your child some of the games you used to play when you were a child, prepare drinks together (lemonade, linden tea) then drink them in a silent part of your house while chatting, renew some parts of the furniture or materials in your house together (For example, sewing new covers for pillows, covering the door of the fridge or dresser with paper, repairing old clothes etc.) and sort out books in the bookcase. Dust your books and put them away, take a drawing book and crayons and go to the garden and then paint the flowers, trees you see in the garden. Learn their names, on a piece of paper, tape some materials such as a bottle cap, a straw, ice cream sticks and leaves and try to make some figures from them; make a sandwich and some drink together and then have a picnic in the balcony, garden or any part of the house; go outside and lie on the ground and watch clouds. Then draw these clouds on a drawing sheet; design a kite and try to fly it and design the puppets of the characters from the story books you have 
read by using socks, pieces of paper, clothes etc. Make the puppets talk (Campaign for a Commercial Free Childhood, 2011).

At the end of the one-week period spent without screen, families need to evaluate the time spent inside and outside the home, their observations made during the activities, differences seen in the behaviors of their children to decide how much time they would like to spend in front of the screen together with their children in their future lives.

This research seeks answers to these questions: What are the opinions of the families about the time spent by their children in front of the screen before participating in the project of screen free week? What are the activities conducted by the families during the screen free week? What are the opinions of families about the project of screen free week? What are the suggestions of families to spend the screen free week more efficiently?

\section{Literature Review}

When the literature is reviewed, it is seen that there are many theories focusing on the relationship between the child and media. For example, the social cognitive theory developed by Bandura (2002) focuses on explaining how the content of the media affects the child's social behaviors on the basis of the idea that children learn within the context of social relationships. Likewise, in the social learning theory (Bandura, 1976), it is stated that the media may be a tool for observing the appropriate and unfavorable behaviors of the child, considering that the child has entered the behavior development process by means of model-taking through observations. On the other hand, the theorist argues that if the media is providing new information and enhancing motivation to learn, then it can be included in the developmental process of the child. The cultivation theory argues that the content seen on the screen affects the viewer's beliefs about the world and, as a result, leads to changes in his/her behaviors. For example, according to this theory, children come to conclusion that aggression is a problem-solving method through exposure to violent publications / games, and as a result, aggressive behaviors in social life become unavoidable (Gerbner, Gross, Morgan, Signorielli \& Shanahan, 2002). The theory of motivation suggests that the influence of the media depends on which media tools are used, the source of motivation (learning and entertainment), and the user's personal competence and organization. Thus, it is maintained that a great care should be taken while selecting media tools and contents. According to the replacement theory, which focuses on the time we spend on communication activities, the use of media tools steals time because it prevents a child from performing other activities that will support the development of the child. According to the replacement theory, it must be taken into account which activities have been replaced and how important these activities are for the child. For example, the time spent studying or sleeping is replaced by the time spent in front of the screen or the time spent playing outside is replaced by the time spent playing games in the tablet (Hofferth, 2010).

Many studies planned on the basis of the above-mentioned theories have revealed the effects of media on the child. While some of these studies focus on the positive effects of media such as promoting the development of language and math skills, early literacy, problem solving skills and visual attention skills (Anderson, Huston; Schmitt, Linebarger \& John, 2001; Attewell, Suazo-Garcia \& Battle, 2003; Fisch, 2004), some others provide evidence on the negative effects of media such as increasing aggression, preventing engagement in outdoor activities, deteriorating social behaviors (Kabaday1, 2012; Anderson \& Bushman, 2001; Anderson, 2002; Van Evra, 2004). The studies mentioning positive effects of media point to the importance of limited use of media tools and the content made up of interaction-based educational games and programs. The view of NAEYC (2012) seems to be supporting these studies. In fact, the use of media tools that do not require the active participation of a child and that are only watched (e.g. television, video) is not recommended in the pre-school period. On the other hand, it is argued that interactive media content entailing active participation, promoting the creativity of the child and allowing group work will support the development of the child.

\section{Method}

In the current study, the instrumental case study method; one of the qualitative research methods, was employed. In the instrumental case research, the researcher focuses on a subject or a problem and then selects a limited case to exemplify this subject (Creswell, 2007). This research focuses on the ways of moving children away from the screen and aims to examine the case in detail on the basis of the project of screen free week sample.

\subsection{Study Group}

The current study employed the purposive sampling method, frequently used in case studies (Creswell, 2007). In this connection, five children attending the preschool class of an elementary school in the Kartal district of İstanbul and 
their families voluntarily participating in the project of screen free week constituted the study group in the current research. Three of the children are girls and two are boys. The families participating in the project of screen free week reported that the time spent in front of the screen by their children before participating in the project was between 1,5 and 3 hours a day.

\subsection{Data Collection Tools}

In case studies, in order to obtain detailed information, generally more than one data collection method is used to collect data (Creswell, 2007). In the current study, documents and structured interview form were used to collect data. The document used to collect data is the weekly chart in which the families noted the activities they performed during the week spent without screen. The structured interview form was developed by the researcher by reviewing the related literature. In order to test the suitability of the interview questions for the purpose of the study, opinions of two experts in the field of pre-school education were sought (Yıldırım and Şimşek, 2013). The questions included in the form are these; 1) What were your feelings and opinions about the time spent by your children in front of the screen before participating in the project of screen free week? 2) How do you evaluate the week spent by your children without screen? 3) What are your suggestions to increase the efficiency of the project of screen free week?

\subsection{Data Collection Process}

The researcher first informed the teacher about the project of screen free week. This project has been implemented by the Campaign for a Commercial Free Childhood (CCFC) since 1995. The researcher examined the Screen Free Week Kit issued by the Campaign for a Commercial Free Childhood in 2011. By taking this guidebook as a reference, the Screen Free Week Guidebook was prepared for Turkish children. In the Screen Free Week Guidebook, there are the main headings of "What is Screen Free Week? Why was the Time of the Project Set as One Week? What Will We Do in the Screen Free Week?" and Screen Free Week Activity Archive and Pre-school Children's Books List. The teacher informed the families about the project of screen free week in the parent-teacher meeting held in November and determined the families wanting to participate on a volunteer basis. Thus, five volunteer families were determined. The volunteer families were given the screen free week guidebook, a one-week chart and one form of written opinions. At the end of the one-week period, the families gave the weekly charts in which they had written the activities they conducted and the written interview forms back to the teacher.

\subsection{Data Analysis}

Content analysis was conducted on the data collected in the current research. In content analysis, similar data are subsumed under the same concepts and themes and then interpreted (Yıldırım and Şimşek, 2013). First the opinion forms collected from the families were read several times and codes were determined. The data obtained in this way in relation to the themes, categories and sub-categories are given in the table and then explained. In addition to this, the families' opinions are also supported with direct quotations made from their statements. The families are coded as A.1, A.2 ... For the validity of the data, triangulation method was used. In triangulation which is one of validation strategies researchers make use of multiple and different sources, methods, investigators and theories to provide corroborating evidence (Miles \& Huberman, 1994; Creswell, 2007). Creswell (2007) mentions that this process involves collecting evidence from different sources to shed light on a theme or perspective. Thus, the current study utilized both documents and interview forms. The data obtained in this way were coded separately by two experts in the field of pre-school education and the inter-coder agreement was tested and the inter-rater reliability was found to be .98 .

\section{Results}

In this section, the findings obtained from the written interview forms and notes taken in the weekly journals by the families are presented.

\subsection{Results Obtained from the Written Interview Forms}

It is seen in Table 1 that the data derived from the families' opinions of the project of screen free week were examined under the themes of time spent before screen free week, screen free week and suggestions. When the categories and sub-categories related to the theme of the time spent with screen before screen free week are examined, it is seen that a great majority of the families (4/5) find the time spent by their children in front of the screen worrying. Only one family stated that it is normal: A.3 "I think the time is normal. In general, if there is nothing to do at home or any other place or if I have something to do at home, then he/she plays games on the mobile phone, watches TV or spends time on his/her own". The families thinking that the time spent in front of the screen by their children is too much stated that their children sit watching TV too long and watch a large number of cartoons. 
A.1: "The time spent by him/her in front of the screen is highly worrisome. He/she watches too many cartoons". Some of the families finding the time spent in front of the screen worrying stated that they try to intervene by drawing their children's attention to something else, switching to programs that do not interest them or lying down some rules. A.4: "We set a limit to the time spent on the screen (1 hour 15 minutes), yet when the child got bored, he/she wanted TV or mobile phone. We tried but failed". As seen in the statement of A.3, families recognized that their children used TV or mobile phones more as there was nobody to interest in the child. One of these families is A.2: "When there is no activity done at home or while we are doing the chores at home, the child immediately starts to watch TV." When the categories and sub-categories belonging to the theme of screen free week are examined, it is seen that all of the families are of the opinion that they spent the week efficiently. In this connection, families expressed their opinions as follows; A.1: "my child used to eat in front of the screen. This habit of his/hers changed somehow this week". A.5: "I observed in this week that my child created games on his/her own. By using the names of the characters he/she learned from the story books we read to him, he/she made up his/her own stories and told them to us". A.4: "I thought that he/she would want me to turn on the television but he/she did not". A.3: "We realized that we had more interactions with our child when we had a screen free life. We tried to spend quality time with him/her as much as we could. Even if there is no screen at home, it can be in our neighbors; that is, it is somehow in our life. To make screen free life more widespread and permanent, everybody should be made more conscious". When the categories and sub-categories related to the suggestions are examined, it is seen that three of the families made one suggestion. In the sub-category of suggestions to families, two of the families stated that they were able to shorten the time spent in front of the screen when they spent time with their children. Therefore, they suggested to other families that they should increase the time they spend with their children. One family on the other hand made a suggestion to teachers:" The teacher can tell children that it is forbidden to watch TV more than 15 minutes at home and that he/she will check it by asking their parents".

Table 1. Themes, Categories and Sub-Categories Derived from the Families' Opinions about the Project of Screen Free Week

\begin{tabular}{|c|c|c|}
\hline Themes & Categories & Sub-categories \\
\hline Before Screen Free Week & Worrying (4) & Cartoons \\
\hline Time Spent on the Screen & Normal (1) & $\begin{array}{l}\text { Very long time } \\
\text { Drawing their attention to } \\
\text { something else } \\
\text { Watching programs on TV that are } \\
\text { nor interesting to them } \\
\text { Only child programs } \\
\text { Interventions that fail when not } \\
\text { enough care is taken }\end{array}$ \\
\hline Screen Free Week & Efficient (5) & $\begin{array}{c}\text { Quality interaction } \\
\text { Quality time } \\
\text { Changes in harmful habits } \\
\text { Happy } \\
\text { Spending time on their own } \\
\text { Creating games } \\
\text { Increasing time spent playing }\end{array}$ \\
\hline Suggestions & $\begin{array}{l}\text { Suggestions to families (2) } \\
\text { Suggestions to teachers (1) }\end{array}$ & $\begin{array}{c}\text { Increasing the time spent with the } \\
\text { child } \\
\text { Producing creative activities }\end{array}$ \\
\hline
\end{tabular}

\subsection{Results Obtained from the Weekly Charts Written by the Families During the Project Week}

When the weekly charts collected from the families were examined, it was found that one of the families had not completed it. In the weekly charts of the two families, it was found that they allocated some time for watching cartoons on TV, contrary to the aim of the project. In Table 2, themes, categories and sub-categories derived from the weekly charts of the families are presented in Table 2 . 
Table 2. Themes, Categories and Sub-Categories Derived from the Weekly Charts Completed by the Families During the Screen Free Week

\begin{tabular}{|c|c|c|}
\hline Themes & Categories & Sub-categories \\
\hline $\begin{array}{l}\text { Activities performed by children } \\
\text { on their own }\end{array}$ & $\begin{array}{l}\text { Conflicting with the aim of the } \\
\text { project (2) } \\
\text { Complying with the aim of the } \\
\text { project (2) }\end{array}$ & $\begin{array}{l}\text { Toys } \\
\text { Watching TV }\end{array}$ \\
\hline $\begin{array}{l}\text { Activities done together with } \\
\text { friends }\end{array}$ & $\begin{array}{l}\text { Complying with the aim of the } \\
\text { project (4) }\end{array}$ & $\begin{array}{l}\text { Game } \\
\text { Park } \\
\text { Art activity } \\
\text { Birthday party } \\
\text { Theatre }\end{array}$ \\
\hline $\begin{array}{l}\text { Activities conducted together with } \\
\text { the family }\end{array}$ & $\begin{array}{l}\text { Complying with the aim of the } \\
\text { project (4) }\end{array}$ & $\begin{array}{l}\text { Meeting with relatives } \\
\text { Beach } \\
\text { Jigsaw } \\
\text { Chatting } \\
\text { Role-play } \\
\text { Bicycle } \\
\text { Child magazine } \\
\text { Blind man's buff } \\
\text { Hide and seek } \\
\text { Painting } \\
\text { Tennis } \\
\text { Playing marbles } \\
\text { Face painting } \\
\text { Activity book } \\
\text { Local market place } \\
\text { Card games } \\
\text { Cake making } \\
\text { Play dough } \\
\text { Popcorn } \\
\text { Helping with house chores } \\
\text { Feeding fish from a ferry }\end{array}$ \\
\hline
\end{tabular}

As can be seen in Table 2, the data derived from the weekly charts are examined under three themes: activities done by children on their own, activities conducted together with friends and activities conducted together with families. Under the theme of the activities done by children on their own, two families mentioned the activity of playing with toys and two families mentioned the activity of watching TV. Of these sub-categories, the activity of watching TV is taken under the category of activities conflicting with the aim of the project. When the theme of activities conducted together with friends is examined, it is seen that all the activities reported by the four families are in compliance with the aim of the project. Finally, when the theme of activities conducted together with the family is examined, it is seen that the activities conducted by the four families comply with the aim of the project. When the sub-categories of this category are examined, it is seen that there is a greater variety of activities here when compared to the other categories.

\section{Discussion}

When the findings obtained from the project of screen free week carried out with the participation of five families having children attending a pre-school education institution are examined,

It is seen that the families find the time spent by their children in front of the screen worrying. This finding, considering the information given by parents about the time spent by their children in front of the screen (it is between 1 and 3 hours a day), concurs with the related literature. In this regard, The American Academy of Pediatrics (2016) warns families about the issues related to children and media on the basis of its observations. It is suggested 
that children under the age of 2 should not spend time in front of the screen and for pre-school children, the time spent in front of the screen should be limited to 1 hour a day (if the family prefers to introduce the child to the screen). If this time is exceeded, then serious threats can be posed to the health and development of the child. In the pre-school period, long time use of media increases the risk of obesity (Cox, Skouteris, Rutherford, Fuller-Tyszkiewicz, Dell' Aquila \& Hardy, 2012), decreases sleep time (Cespedes, Gillman, Kleinman, Rifas-Shiman, Redline \& Taveras, 2014), results in retardations in cognitive, linguistic an social/affective development (Oral Paksoy, 2017; Lin, Cherng, Chen, Chen YJ, Yang, 2015; Duch, Fisher, Ensari et al., 2013; Manganello \& Taylor, 2009) and leads to weakening in executive functions (Nathanson, Aladé, Sharp, Rasmussen \& Christy, 2014). In addition to this, it was determined that there is a relationship between the long-time use of media in the pre-school period and school achievement, the state of performing physical activity and of being subjected to peer bullying in the secondary school (Pagani, Fitzpatrick, Barnett \& Dubow, 2010). In a study conducted by İnanl1 (2015) on 52 Turkish children aged at 4-6, it was found that there is a significant relationship between the increasing time spent using media tools and aggressive behaviors. Another study reporting a significant relationship between the time spent on media and aggressive behaviors found that with increasing TV viewing time of 105 children aged at 3-6, their social behaviors decrease and physical and relational aggressive behaviors increase (Akçay and Özcebe, 2012). Considering the time spent in front of the screen from a different point of view, Buijzen and Valkenburg (2003) and Schor (2004) point out that children are exposed to many advertisements while they are at the screen and according to them, these advertisements make children more materialist and unhappy and increase the risk of conflict between the child and parents.

All of the families participating in the study are of the opinion that the screen free week was fruitful. The families stated that they established more interactions with their children, the number of games played and creative activities done at home increased and they felt that their children were happier. These statements of the families are supported by the findings in the literature. For example, Vandewater, Bichham \& Lee (2006) revealed that with the increasing time spent in front of the screen, the interaction with the family weakens and the number of creative games decreases. Moreover, the American Academy of Pediatrics (2016) underlines the importance of family-child interaction for many developmental skills of the child. It argues that taking responsibility, being persistent on completing an activity, impulse control, affect regulation and higher thinking skills such as creative and flexible thinking can be learned best through unstructured social games and quality family-child relationships.

When the weekly charts filled in by the families were examined, it was found that one family did not complete the weekly charts and half of the other families (2/4) could not spend the week without the screen. In the charts of these two families, it was frequently indicated that the child watched cartoons. In addition to this, though the families were asked to note the activities they did in screen free times, they also wrote such expressions as "he/she went to school", "he/she played with school mates" in their weekly charts. Though the families stated that they felt that they established more interactions with their children in screen free times, this was not apparent in their weekly charts. Most of the sub-categories subsumed under the theme of activities conducted together with the family were only mentioned by one family. In the Screen Free Week Guidebook, a total of 82 activities that can be done by children on their own, together with their peers and family members are proposed. It was determined that only one of the families made use of these proposed activities and tried to spend the week with various activities.

At the end of the project of screen free week, the families were asked to evaluate the week they spent without screen and to determine how much time they would allocate for the screen in their future lives. On the basis of the families' responses and their weekly chart data, it was determined that one family decided not to put a screen limit, three families decided to put a limit of one hour and one family decided to put a limit of 30 minutes. The families were asked to receive information and approval from the teacher about what their children should watch and play. What children are exposed to on the screen is as important as the time spent in front of the screen. What is emphasized here is the necessity of determining whether applications/programs the child sees on the screen are high quality. The family should watch together with the child while he/she is in front of the screen, help the child to understand what he/she sees and more importantly encourage him/her to apply what he/she has learned to the world around him/her. Unfortunately, many programs categorized as educational in the tablet, mobile phone and television include violence, fast screen images etc. (Campaign for a Commercial Free Childhood, 2011). Though there is some evidence showing that high quality applications, TV programs (e.g. Sesame Street) have positive effects on children's social, cognitive and linguistic development, there is no such evidence proving the efficiency of many applications and programs classified as educational. It has been stated that many of these applications only focus on academic achievement, they have not been designed according to some certain criteria, they are not built on a specific developmental infrastructure, they have not been submitted to the scrutiny of the experts of child development and education 
(Chiong \& Shuler, 2016; Guernsey \& Levine, 2015) and when they are not used together with the family, they have some negative effects on the development of language skills (Bus, Takacs \&Kegel, 2015; Golinkoff \& Hirsh Pasek, 2006). In the study conducted by Ergüvey (2017) on 16 Turkish children, the effect of the content reached through media tools on their behaviors was revealed. The author found that considerable time is spent on the Internet by children aged at 3-6 (time ranging from 1 hour to 4 hours). It was also found that nearly half of the families participating in the study never control their children while they are on the Internet and do not take any precautions against harmful content. As a result, it was revealed that families are of the opinion that the content reached by their children has negative effects on their linguistic development, consumption patterns, intra-family communication and socialization.

The decision to limit the time spent in front of the screen should be made by families after experiencing screen free time and together with their children and they should consult teachers about what should be watched/played on the screen. All of these are important in terms of sustainability. At the end of the screen free week project, the Campaign for a Commercial Free Childhood (2011) categorized children's decisions about how much time they would allocate to the screen in their future lives into four groups. Golden Group: Weekdays are spent screen free. At the weekend, at most 30 minutes in front of the screen each day (Requirements: Informing classroom teachers and receiving his/her approval about the cartoons, films, series to be watched and tablet, mobile phone and computer games to be played). Silver Group: At most 30 minutes in front of the screen each day (Requirements: Informing classroom teachers and receiving his/her approval about the cartoons, films, series to be watched and tablet, mobile phone and computer games to be played). Bronze Group: At most 60 minutes in front of the screen each day (Requirements: Informing classroom teachers and receiving his/her approval about the cartoons, films, series to be watched and tablet, mobile phone and computer games to be played). Group of those not being able to control time spent in front of the screen: Without any limitation, the child spends as much time as he/she wishes in front of the screen. According to this classification, one of the participating families in the current research is in the silver group; three of them are in the bronze group and one of them is in the group of those not being able to control the time. When the suggestions of the family not being able to control the time spent in front of the screen for the screen free week are examined, the evidence of their inability to control the time is seen because this family suggested that the teacher should warn children in the class and should tell them that he/she would learn how much time they had spent watching TV from their families. This suggestion can be regarded as the indication of their inability to control the time. It is understood that the family is in the pursuit of help from an external authority. However, in the project of screen free week, the aim is to increase the time allocated to family-child interaction and to decrease the time spent in front of the screen via intrinsic motivation. Instead of training externally controlled children, it is aimed to provide guidance for children to regulate their own behaviors.

None of the families participating in the study made a decision to limit the time spent in front of the screen to 30 minutes at most each day at the weekend, so none of them is in the golden group. Yet, the families' being willing to participate in the project of screen free week, to try it, feeling that they established more interaction with their children during the screen free time and seeing it as a fruitful application can be seen as the first step taken in the direction of screen free life. In this project, only five families out of 20 families became volunteers to try this application; only one of these five families was able to experience a real screen free week, indicating that there is a need to raise families' awareness of the issue. On the other hand, high majority of the families participating in the study did not exceed the time limit set by the American Academy of Pediatrics for the time to be spent in front of the screen by pre-school children. Though a decision for a screen free life was not made, it is considered to be important that the families raised their awareness and preferred to limit the time their children spend in front of the screen. Research points out that pre-school period can be a turning point in the prevention of the negative effects of the screen. In their study, Mistry, Minkovitz, Strobino \& Borzekowski (2007) found that television viewing patterns in early ages and behavioral problems seen in later ages are related and if the child is prevented from watching TV for too long before the age of 6 , these problems may not be experienced in later ages. Christakis \& Zimmerman (2006) found that setting a limit to television viewing time before the age of four leads to decreasing interest in television viewing in later ages.

As a result of the families' participation in the project of screen free week and experiencing a screen free week, they recognized the importance of family-child interaction, that their children are happier when they spend time with them, that they can decide on programs to be watched and games to be played together with their children and that this decision should not be taken as a rule rather as a routine of the family. At the end of the project of screen free week, it was seen that a great majority of the families set a limit to the time spent in front of the screen suitable for the age and developmental level of their children. 


\section{Conclusion}

In light of the findings of the current study, it can be suggested that the project of screen free week should be made more widespread and more families and children should be reached. In addition to this, training programs can be organized for families to learn how to select quality programs/applications. For families to experience and evaluate these applications/programs before their children use them, workshops can be organized. More alternative activities to be conducted in a screen free week can be developed. Through cooperation with the directors and teachers of pre-school education institutions, the project of screen free week can be expanded to all the other pre-schools in the province/city. By celebrating the decision made to limit the time spent by children in front of the screen, families and children should be made to feel the importance of the decision and should be motivated. In cooperation with non-governmental organizations such as TEMA, the project of screen free week can be expanded for more children to have screen free lives.

\section{References}

Akçay, D. (2015). Annelerle yapılan motivasyonel görüşmelerin okul öncesi dönemdeki çocuğun medya etkileşimine ve saldırganlık davranışlarına etkisi. Unpublished doctora's thesis. Hacettepe University, Ankara.

Akçay, D., \& Özcebe, H. (2012). Televizyonun okul öncesi dönemdeki çocukların saldırganlık davranışına etkisi. Çocuk Sağlı̆̆l ve Hastalıklarl Dergisi, 55, 82-87.

American Academy of Pediatrics (2016). Media and young minds. https://doi.org/10.1542/peds.2016-2591

Anderson C., \& Bushman, B. (2001). Effects of violent video games on aggressive behvior, aggressive cognition, aggressive affect, physiological arousal, and prosocial behavior. Psychological Science, 12, 353- 359.

Anderson, CA. (2002). Violent video games and aggressive thoughts, feelings, and behaviors. In: Calvert, SL.; Jordan, AB.; Cocking, RR., (eds.), Children in the digital age. Westport, CT: Praeger; p. 101-119. https://doi.org/10.1111/1467-9280.00366

Anderson, DR., Huston, AC., Schmitt, KL., Linebarger, DLW., \& John, C. (2001). Early Childhood Television Viewing and Adolescent Behavior. In: Overton, W., editor. Monographs of the society for research in child development. Vol. 66. Boston, MA: Blackwell.

Attewell, P., Suazo-Garcia, B., \& Battle, J. (2003). Computers and young children: Social benefit or social problem. Social Forces, 82, 277-296. https://doi.org/10.1353/sof.2003.0075

Aydeniz, H. (2012). Bilinçli medya kullanımı. İstanbul: EDAM Eğitim Danışmanlığı ve Araştırmaları Merkezi.

Bandura, A. (2002). Social cognitive theory of mass communication. In: Bryant, J.; Zillmann, D., (eds.), Media effects: Advances in theory and research. 2. Mahwah, NJ: Lawrence Erlbaum; p. 121-153.

Bandura, A. (1976). Social learning theory. In: Spence, J.; Carson, R.; Thibaut, J., (eds.), Behavioral approaches to therapy. Morriston, NJ: General Learning Press. p. 1-46.

Banko, Ç., İlhan, T., \& Şallı, F. (2017). Okul öncesi dönem çocuklarının ebeveynlerinin televizyonda akıllı sembol kullanımı ve çocuklarını televizyondan koruma yöntemleri. Erken Çocukluk Çalışmaları Dergisi, 1(1), 45-59. https://doi.org/10.24130/eccd-jecs.196720171114

Buijzen, M., \& Valkenburg, P. (2003). The effects of television advertising on materialism, parent child conflict and unhappiness. A review of research. Applied Developmental Psychology, 24, 437-456. https://doi.org/10.1016/S0193-3973(03)00072-8

Bus, A.G., Takacs, Z.K., \& Kegel, C.A. (2015). Affordances and limitations of electronic storybooks for young children's emergent literacy. Dev Rev., 35, 79-97. https://doi.org/10.1016/j.dr.2014.12.004

Campaign for a Commercial Free Childhood (2011). Screen free week 2011 organizer's kit. Boston: Campaign for a Commercial Free Childhood.

Cespedes, E.M., Gillman, M.W., Kleinman, K., Rifas-Shiman, S.L., Redline, S., \& Taveras, E.M. (2014). Television viewing, bedroom television, and sleep duration from infancy to mid-childhood. Pediatrics, 133(5). https://doi.org/10.1542/peds.2013-3998

Chiong C., \& Shuler C; (2016). The Joan Ganz Cooney Center at Sesame Workshop. Learning: Is there an app for that? Investigations of young children's usage of learning with mobile devices and apps. Retrieved from http://dmlcentral.Net. 
Christakis, D., \& Zimmerman, F. (2006).Early television viewving is associated with protesting turning of the television, at age 6. Medscape General Medicine, 8(2), 63.

Cox, R., Skouteris, H., Rutherford, L., Fuller-Tyszkiewicz, M., Dell’ Aquila, D., \& Hardy, L.L. (2012). Television viewing, television content, food intake, physical activity and body mass index: a cross-sectional study of preschool children aged 2-6 years. Health Promot J Austr., 23(1), 58-62. https://doi.org/10.1071/HE12058

Creswell, J. (2007). Qualitative inquiry and research design: Choosing among five approaches (2nd ed.). Thousand Oaks, CA: Sage.

Duch, H., Fisher, E.M., \& Ensari, I. et al. (2013). Association of screen time use and language development in Hispanic toddlers: a cross-sectional and longitudinal study. Clin Pediatr (Phila)., 52(9), 857-865. https://doi.org/10.1177/0009922813492881

Dorey, E., Roberts, V., Maddison, R., Meagher-Lundberg, P., Dixon, R., ve Mhurchu, C. N. (2010). Children and television watching: a qualitative study of New Zealand parents' perceptions and views. Child: Care, Health And Development, 3, 414. https://doi.org/10.1111/j.1365-2214.2009.01031.x

Ergüvey, M. (2017). İnternetin okul öncesi dönemdeki çocuklar üzerindeki etkileri hakkında bir araştırma. ulakbilge, 5(17), 1917-1938.

Fisch, SM. (2004). Children's learning from educational television: Sesame Street and beyond. Mahwah, NJ: Lawrence Erlbaum.

Gerbner, G., Gross, L., Morgan, M., Signorielli, N., \& Shanahan, J. (2002). Growing up with television: Cultivation processes. In: Bryant, J.; Zillmann, D., editors. Media effects: Advances in theory and research. 2. Hillsdale, NJ: Lawrence Erlmann. p. 43-67.

Golinkoff, RM., \& Hirsh Pasek, K. (2006). How toddlers begin to learn verbs? Trends in Cognitive Science, 12, 397 403. https://doi.org/10.1016/j.tics.2008.07.003

Guernsey, L., \& Levine, M.H. (2015). Tap Click Read: Growing readers in a world of screens. San Fransisco, CA: Jossey-Bass.

İnanl1, S. (2015). Preschool - aged children's media use and its relationship to their prosocial and aggressive behavior. Unpublished master thesis. Boğaziçi University, İstanbul.

Kabadayı, A. (2012). 0-6 Yaş Çocuğun Tv İzleme Davranışları ve Tv Programlarının Çocuğa Etkileri Üzerine Ebeveyn Görüşleri. Sözlü bildiri. Uluslararası Katılımlı Kadına ve Çocuğa Karşı Şiddet Sempozyumu, 27-28 Nisan, Ankara, Turkey.

Lin, L.Y, Cherng, R.J., Chen, Y.J., Chen, Y.J., \& Yang, H.M. (2015). Effects of television exposure on developmental skills among young children. Infant Behavior and Development, 38, 20-26. https://doi.org/10.1016/j.infbeh.2014.12.005

Manganello, J.A., \& Taylor, C.A. (2009). Television exposure as a risk factor for aggressive behavior among 3 years old children. Archives of Pediatric and Adolescent Medicine, 163(11), 1037-1045. https://doi.org/10.1001/archpediatrics.2009.193

Miles, M. B., \& Huberman, A. M. (1994). Qualitative data analysis. Thousand Oaks, CA: Sage.

Mistry, K.B., Minkovitz, C.S., Strobino, D.M., \& Borzekowski, D.L.G. (2007). Children's television exposure and behavioral and social outcomes at 5.5 years. Does timing of exposure matter? Pediatrics, 120, 762-769. https://doi.org/10.1542/peds.2006-3573

National Association for the Education of Young Children and Fred Rogers Center for Early Learning and Children's Media. (2012). Technology and interactive media as tools in early childhood programs serving children from birth through age 8: A joint position statement.

Nathanson, A.I., Aladé, F., Sharp, M.L., Rasmussen, E.E., \& Christy K. (2014). The relation between television exposure and executive function among preschoolers. Dev Psychol., 50(5), 1497-1506. https://doi.org/10.1037/a0035714

Oral Paksoy, S.A. (2017). Okul öncesi dönem çocuklarının televizyon izleme ve bilgisayar oynama sürelerinin görsel-motor entegrasyonu açısından incelenmesi. Unpublished master thesis. Necmettin Erbakan University, Konya. 
Pagani, L., Fitzpatrick, C., Barnett, T. A., \& Dubow, E. (2010). Porspective associations between early childhood television exposure and academic, psychosocial and physical well being by middle childhood. Archives of Pediatric and Adolescent Medicine, 164(5), 425-431. https://doi.org/10.1001/archpediatrics.2010.50

Schor, J. (2004). Born to buy. The commercialized child and new consumer culture. New York. Scribner, p. 167.

Vandewater E. A., Bickham, D.S., \& Lee, J. H. (2006). Time well spent? Relating television use to children's free time activities. Pediatrics, 117(2), 181-191. https://doi.org/10.1542/peds.2005-0812

Van Evra, J. (2004). Television and child development. Mahwah, NJ: Erlbaum.

Yıldırım, A., \& Şimşek, H. (2013). Sosyal bilimlerde nitel araştırma yöntemleri. Ankara: Seçkin Yayıncılık. 